\title{
CADASIL Syndrome Presenting as Adjustment Disorder
}

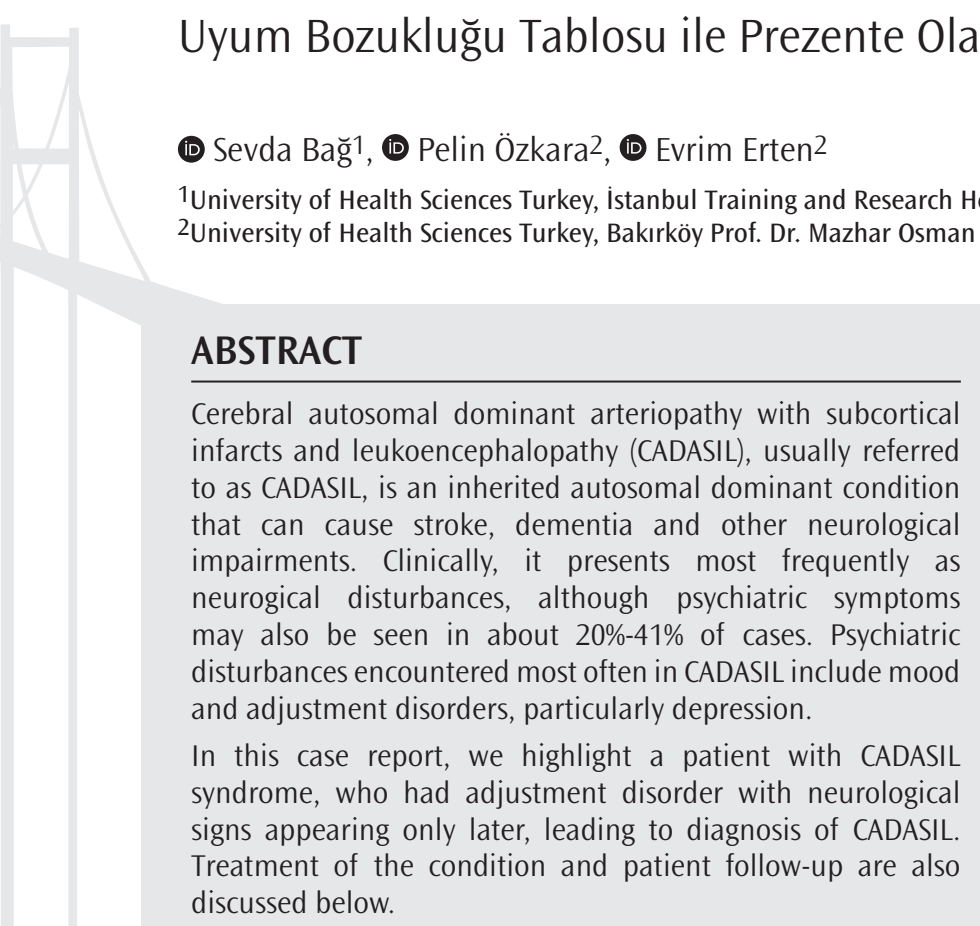

\section{$\ddot{0} Z$}

Subkortikal enfarkt ve lökoensefalopati ile giden otozomal dominant serebral arteriyopati (CADASIL) yetişkinlerde inme ve vasküler demansın en sık ailesel nedenidir. CADASIL tanısı almış hastalarda nörolojik bozukluklar daha ön planda olsalar da psikiyatrik bozukluklara rastlanma oranı \%20-\%41 arasında değişmektedir. Duygudurum bozuklukları ve uyum bozuklukları en sık eșlik eden psikiyatrik bozukluklardır. Bu yazıda depresif mizaçıı uyum bozukluğu tanısı ile yatışı yapılan hastada ortaya çıkan nadir rastlanan bir nörolojik hastalık olan CADASIL olgusu ve tedavi ve izlem süreci tartışılacaktır.

Anahtar Kelimeler: CADASIL, uyum bozukluğu, depresyon

Keywords: CADASIL, adjustment disorder, depression

\section{Introduction}

Autosomal dominant cerebral arteriopathy and a small vascular disease, leading to subcortical infarction and leukoencephalopathy cerebral autosomal dominant arteriopathy with subcortical infarcts and leukoencephalopathy (CADASIL) is the most common familial cause of stroke and vascular dementia that develops due to small vessels in adults (1). Clinically; it is characterized by migraine, lacunar stroke or transient ischemic attack, cognitive disorders and psychiatric disorders (2). CADASIL is caused by a mutation in the NOTCH3 gene located on the $19^{\text {th }}$ chromosome (3). Although CADASIL is clinically observed in the fourth and fifth decade, migraine attacks with aura are observed in the second and third decade. It has also been suggested that sporadic hemiplegic migraine cases that occur without brain imaging findings may be an initial sign of CADASIL (4). Cognitive impairments seen in CADASIL occur especially in executive functions and attention deficit (5). Widespread hyperintense areas in the white matter are observed in T2-weighted magnetic resonance (MR) imaging of $90 \%$ of the patients. The incidence of hyperintense areas increases dramatically with advancing age (6). In our case, the inability to access T2-weighted MR images constituted the limitation of our article. Pathological examinations showed that it is a non-atherosclerotic disease that does not contain amyloid and affects the walls of small arteries (7). The pathogonomic finding for CADASIL is the demonstration of granular osmophilic material in the tunica media base of the cerebral artery under an electron microscope (8). Although neurological disorders are at the forefront in patients diagnosed with CADASIL, the incidence of psychiatric disorders ranges from $20 \%$ to $41 \%$, and psychiatric findings constitute one of the cardinal characteristics of the disease. The most common of these are mood disorders and adjustment disorders with a rate of 9-41\%. A smaller proportion are also accompanied by psychotic symptoms (9). In this article, a CADASIL case with depressive temperament adjustment disorder will be presented and psychiatric symptoms that can be observed in a rare neurological disease, as well as the diagnosis, treatment and follow-up process will be discussed. 


\section{Case Report}

Forty-year-old, married, without children, fifth of seven siblings, female patient was admitted to the psychiatric training and research hospital inpatient clinic with complaints such as malaise, despair, suicidal thoughts, inability to leave the house, inability to do household chores that have continued for the last 3-4 months.

In his psychiatric evaluation, it was observed that the patient, who looked at her age and was respectful to the interviewer, was conscious and oriented, and her self-care was adequate and at her age. During the interview, affect was evaluated as tearful and her mood as dysphoric. Although the speed and amount of speech decreased, the patient, whose associations were regular, could turn towards the goal. In her thought content, there were themes of psychosocial stressors that developed due to the relationship of her husband with another person and the threat of the other party's family to her and her sisters. She didn't describe delusions or hallucinations. When the patient's life history was deepened, it was learned that she had been admitted to the outpatient clinic with existing complaints a few months ago and was taking sertraline $100 \mathrm{mg} /$ day and mirtazapine $15 \mathrm{mg} /$ day. The patient was diagnosed with depressive temperament adjustment disorder, as it was observed that the events she experienced had affected her life for the last few months, she remained between her family and her marriage due to the events, her problems increased with the thought of separation from her spouse and her functionality decreased significantly, these depressive symptoms did not occur on the basis of a personality pathology and did not result from the grief process.

In the history of the patient, it was learned that there were headache attacks that started since the age of 18 and gradually increased, preceded by nausea and flies, and that she could not write intermittently during these attacks, intermittent speech, occasional gazing on and staring. In her family history, her mother was treated for migraine-type headache with aura, and her uncle had numbness in the tongue, speech disorder, and migraine-type headache; one of her siblings occasionally complained of not being able to speak, another sibling 4-5 years ago numbness in the face, weakness in the hands; in the other sibling, it was learned that complaints such as forgetfulness, loss of strength in the arm, numbness in the lips and inability to speak were recovered from time to time.

As a result of neurology consultation examination, brain MR imaging report performed in different centers, hyperintensities in cerebral hemispheres; on the observation of hyperintense signal changes in the temporal lobes, subcortical and periventricular white matter areas, external capsules, adjacencies of the temporal, occipital and frontal horns of the lateral ventricle, and in a patchy form with diffuse confluency in the corona radiata, periventricular and subcortical white matter areas at the centrum semiovale level, it was stated that the diagnosis of CADASIL was considered. We think that the limitation of our article is that we could not access T2 flair images of our case because they were performed at a different center (Figure 1). In addition, our patient was subjected to a mini mental status examination test and it was evaluated as a mild cognitive impairment with a 24/30 result. It was learned that the diagnosis of CADASIL was confirmed by detecting
NOTCH3 gene mutation in genetic tests. After the diagnosis of CADASIL was made, it was learned that the gene analysis was performed in all 4 siblings, and the other siblings had NOTCH3 gene mutation and the other two siblings did not admit to the hospital voluntarily.

The patient was followed up in our inpatient clinic. The patient, who was clarified to be CADASIL after neurological consultation, was referred to the neurology outpatient clinic after the completion of her acute psychiatric treatment. Our patient still continues to follow up regularly and is in remission.

Informed consent was obtained from the patient for a case report.

\section{Discussion}

CADASIL is an extremely rare genetic disease that most commonly occurs as transient ischemic attacks. It has been reported that cognitive impairment is seen in $48 \%$ of CADASIL cases, dementia seen in $28 \%$ of cases is accompanied by $90 \%$ gait disturbances, $86 \%$ urinary insufficiency, and $52 \%$ pseudolbulbar palsy. Eigthty seven percent of migraines seen in 38\% of cases are migraine with aura, but migraine without aura can also be accompanied. In our case, a slight level of cognitive impairment was detected in a psychometric examination. In the family history of our case, migraine type headache present in all sisters and grandmother is consistent with CADASIL, an autosomal dominant cerebral arteriopathy. The diagnosis of CADASIL is made clinically, at a relatively young age, in the presence of lacunar infarcts that develop in the absence of any risk factors such as hypertension or arteriosclerosis, and when other members of the family have a similar situation (10). CADASIL is often accompanied by psychiatric disorders. In a study conducted by Peters et al. (11) with 80 CADASIL patients, the rate of major depression was found to be $10 \%$ (11). Bipolar mood disorder (12), psychotic disorders (13) accompanying CADASIL are included in the literature (Table 1). In our case, depressive temperament adaptation disorder is at the forefront.

In our case, the emergence of symptoms due to the marital problems he experienced in the last months and the partial benefit from the treatment made us think that she could not cope with the stress present in the diagnosis rather than the mood disorder and that the problems of adaptation were more prominent.

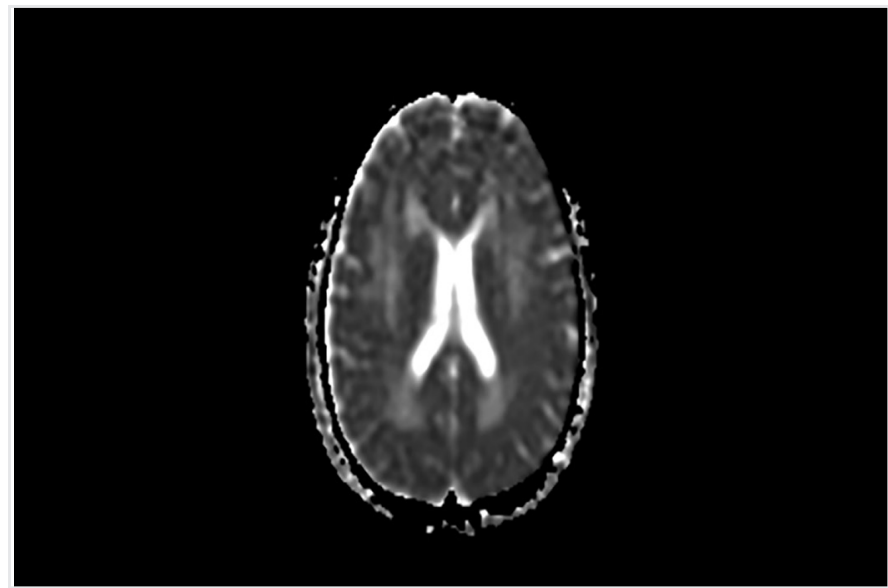

Figure 1. Cranial magnetic resonance image 


\begin{tabular}{|l|l|l|}
\hline \multicolumn{3}{|c|}{ Table 1. Psychiatric tables accompanying CADASIL } \\
\hline & $\begin{array}{l}\text { Number of } \\
\text { patients }\end{array}$ & $\begin{array}{l}\text { Psychiatric } \\
\text { disorder }\end{array}$ \\
\hline Peters et al. (11) (2005) & 80 & Major depression (10\%) \\
\hline Dichgans et al. (14) (1998) & 102 & Adjustment disorder (23\%) \\
\hline Mishra et al. (13) (2018) & Case report & Psychosis \\
\hline Kesebir et al. (12) (2010) & Case report & Bipolar disorder \\
\hline
\end{tabular}

In the study of Dichgans et al. (14), 102 CADASIL patients were followed and adjustment disorder was found in 24 . We think that the reason for the adjustment disorder that developed in our case was the difficulty in coping with the stress in her life due to this disease. In one study, it was shown that the depressive complaints accompanying CADASIL negatively affect the quality of life. Quality of life is also very low in our case (15).

In conclusion, accompanying headaches in patients presenting with adjustment disorder and a similar history in family members should bring to mind the possibility of CADASIL, which is rarely encountered, and it is recommended to follow the disease with neurological follow-up and treatment and additional supportive treatments for the crisis given to the patient.

\section{Ethics}

Informed Consent: Informed consent was obtained from the patient for a case report.

Peer-review: Externally peer-reviewed.

Authorship Contributions: Concept - P.Ö.; Design - S.B.; Data Collection or Processing - S.B.; Analysis or Interpretation - E.E.; Literature Search P.Ö.; Writing - S.B.

Conflict of Interest: No conflict of interest was declared by the authors.

Financial Disclosure: The authors declared that this study received no financial support.

\section{References}

1. Toni-Uebari TK. Cerebral autosomal dominant arteriopathy with subcortical infarcts and leucoencephalopathy (CADASIL): a rare cause of dementia. Case Rep Child Meml Hosp Chic 2013; 2013: bcr2012007285.
2. Chabriat Hugues, Joutel A, Dichgans M, Tournier-Lasserve E, Bousser MG. "Cadasil." Lancet Neurol 2009; 8: 643-53.

3. Joutel A, Corpechot C, Ducros A, Vahedi K, Chabriat H, Mouton P, et al. Notch3 mutations in CADASIL, a hereditary adult-onset condition causing stroke and dementia. Nature 1996; 383: 707-10.

4. Monteiro C, Barros J, Taipa R, Pereira-Monteiro J. Sporadic hemiplegic migraine as the initial manifestation of Cadasil. Cephalalgia 2012; 32: 255-7.

5. Dominquez-Sanchez FJ, Lasa-Aristu A, Gomi-Imızcoz M. Intelligence impairment, personality and psychopathology disturbances in a familiy affected with Cadasil. Span J Psychol 2011; 14: 936-43.

6. Benisty S, Reyes S, Godin O, Herve D, Zieren N, Jouvent E, et al. White matter lesions without lacuner infarcts in Cadasil. J Alzheimers Dis 2012; 29: 903-11.

7. Uchino M. The pathomechanism and treatment of CADASIL. Rinsho Shinkeigaku 2011; 51: 945-8.

8. Chabriat H, Vahedi K, Bousser MG, Iba-Zizen MT, Joutel A, Nibbio A, et al. Clinical spectrum of CADASIL: a study of seven families. Lancet 1995; 346: 934-9.

9. Valenti R, Poggesi A, Pescini F, Inzitari D, Pantoni L. Psychiatric disturbances in CADASIL: A brief review. Acta Neurol Scand 2008; 118: 291-5.

10. Desmond DW, Moroney JT, Lynch T, Chan S, Chin SS, Mohr JP. The natural history of CADASIL: a pooled analysis of previously published cases. Stroke 1999; 30: 1230-3.

11. Peters N, Opherk C, Danek A, Ballard C, Herzog J, Dichgans M. The pattern of cognitive performance in CADASIL - a monogenic condition leading to subcortical ischemic vascular dementia. Am J Psychiatry 2005; 162: 2078-85.

12. Kesebir S, Koca EK, Kilicaslan EE. CADASIL Syndrome presenting with bipolar disorder. J Mood Disord 2010; 2: 115-8.

13. Mishra DK, Kishore A, Niranjan V. CADASIL syndrome (cerebral autosomal dominant arteriopathy with subcortical infarcts and leukoencephalopathy) presenting as psychosis. Gen Psychiatr 2018; 31: e100017.

14. Dichgans M, Mayer M, Uttner I, Brüning R, Müller-Höcker J, Rungger G, et al. The phenotypic spectrum of CADASIL: clinical findings in 102 cases. Ann Neurol 1998; 44: 731-9.

15. Brookes RL, Willis TA, Patel B, Morris RG, Markus HS. Depressive symptoms as a predictor of quality of life in cerebral small vessel disease, acting independently of disability; a study in both sporadic small vessel disease and CADASIL. Int J Stroke 2013; 8: 510-7. 